\title{
Iron and Steel as Materials for Rifled Cannon
}

\section{John Aanderson Esq}

To cite this article: John Aanderson Esq (1862) Iron and Steel as Materials for Rifled Cannon, Royal United Services Institution. Journal, 6:23, 185-201, DOI: 10.1080/03071846209417180

To link to this article: http://dx.doi.org/10.1080/03071846209417180

$$
\text { 曲 Published online: } 11 \text { Sep } 2009 .
$$

Submit your article to this journal

Ш Article views: 1

Q View related articles $₫$ 


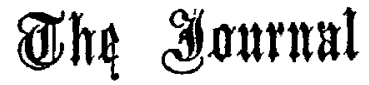

\section{or nax

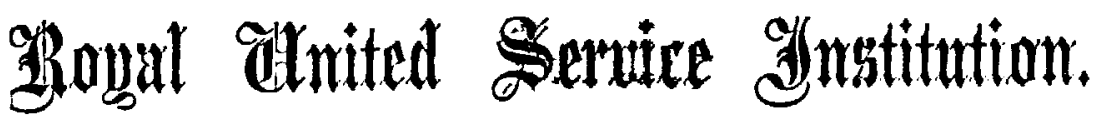

\begin{tabular}{lll}
\hline VOL. TI. & 1862. & No. XXIII.
\end{tabular}

\section{LECTURES.}

Friday, February 14th, 1862.

Captain E. G. FISHBOURNE, R.N., C.B. in the Chair.

\section{IRON AND STEEL AS MATERIALS FOR RIFLED CANNON. \\ By Jour Axdersox, Esq., Assistant Superintendent Royal Gun Factories, Woolmich.}

If the value of a material were to be estinnted by the place which it occupies in the world, in regard to its usefulness for serving the multifarious purposes of mankind, then to the class of metals known as iron and steel in their many modifications must be ascribed an importance and position superior to any of the other mineral substances which have been placed at our disposal.

Iron, including steel, is the great staple article of Britnin, and is the chief agent by means of which this country has been enabled to maintain the prominence she holds among the other nations.

In this country alone abore fire million tons are produced annually; and the increasing applications of those materials, which we daily see going on around us in every branch of the arts of peace, as also their extensire usefulness in connection with the art of war, render it highly necessary that erery intelligent individual should hare some acquaintance with the leading peculiarities of those substances; and the object of the present lecture is -

1st. To point out generally the nature and the leading characteristics of those materials ; and

2nd. To consider their comparative fitness for one of the purposes to which they are applied as munitions of war, namely, riffed camnon.

As there is no other subject in connection with the wide range of practical mechanism engaging more attention at the present time than the one now under consideration, and which is alrendy so well known in many of its details, it caunot be expected that much additional light will be thrown upon it in the present instance, or that any claim for originality can now be made; still it is to be hoped that the first part of the lecture may be useful to some, and that the facts which have come out under my own observation and experiments, which are referred to in the latter part, may be instructive to all.

vor. vi. 
Although iron is frequently referred to in the Old Testament Scriptures, yet re cannot find that it was extensirely used until a much later period; the hindrance to its introduction probably arising from the extreme difficulty experienced in separating it from the earthy matters with which it is found in the condition of "iron ore."

The ores of iron are found extensively scattered all over the world, yet, comparatively speaking, fer are now considered as fitted for the purposes of the iron-maker; questions of quality, means of effecting reduction, and other commercial questions, chiefly determine their ralue.

In Sreden and in some other countries iron ore is found in solid rocks, forming veins in the granite of enormous thickness, such ore being comparativels pure. This ore is supposed to be of rolcanic origin, and, being generally in conjunction with igneous rocks, it in all probability at some remote period was belched out from the molten matter within the globe.

But in this country most of our iron is found mixed up with indurated clay or mud, in lumps or nodules; and it is supposed that these lumps are the mud of such reins of rolcanic iron ore ground down by the geological floods of an early cra.

These lumps are generally found in beds, and frequently just abore and under and alternating with the seams of coal by means of whicls they are to be smelted, and also in close proximity to the refractory material called fire-clay, which is so raluable an agent in their reduction.

Previous to tho smelting process, by which the iron is separated from the carthy matter, it is found necessary to subject the ore to a preliminary process of calcining, or, as it is commonly termed, roasting, which is simply a subjecting of the ore to a continuous dull red-heat for a considerable period in order to drive off the foreign matters which are injurious to the quality of the iron, and also to produce a greater degree of oxidation, as rell as to open up the ore and render the smelting process more easily effected.

The degree of heat employed in roasting, the period of time required, and the description of kiln or oren which is used, depend entirely on the nature of the particular ore, and are found to differ in almost erery locality: in all the object is the same, namels, to keep the ore at such a temperature and for such a length of time as will be sufficient to expel the injurious gases; those conditions of procedure in the great majority of cases being derired from experience rnther than from any chemical knowledge of the changes to be effected.

$U_{p}$ to this stage the ore has but little resemblance to the raluable metal which it contains, and the first great step in adrance is to eliminate the carthy matter and set the iron free.

This is effected in different ways; but the general method is to put the ore and fuel into the furnace together, then to generate an intense heat by means of a strong blast of wind, until the refractory ore is orercome and the iron begins to melt.

Without some other agent to assist, the process of separation rould bo Fery imperfectly accomplished: $:$ it is found necessary to employ what is termed a flux. This flux material is also thrown into the furnace along with the ore and fuel, and the chief object of the flux is to unite with the earthy matter and set free the iron.

With argillaccous or clay ore a calcareons flux, generally limestone, is 
used; with a calcareous ore an argillaceous flux is employed, or, what is better, a mixturo of both descriptions of ore in due proportion.

Under the high temperature within the furnace, the two earthy substances nssimilate and form the glassy slag or scoria, which, being lighter, floats upon the liquid iron at the lorrer part of the furnace, and runs off by an opening left on purpose; while the iron (when a sufficient quantity is collected) is run out upon the floor into the pig-iron of commerce.

From the circunstance that the melting iron is in such intimate contact with the fuel, and from having to pass through it like water through a filter, the quality of the iron is necessarily much aftected by the nature of the fucl, and as it so happens that the presence of sulphur, phospliorus, and other impnrities is found to affect the conditions of strength and other properties of the iron, those descriptions of iron that are made with the purest mineral fuel are the best, supposing other conditions to be the same, and best of all is the iron smelted with the charcoal from rood, which is obviously more free from those injurious properties that belong, more or less, to all mineral fuel used in the iron manufacture on a large scale, with which I am acquainted.

By subjecting mineral conl to the process of coling, it is purified to a considerable extent, still the iron which is made eren with coke is not of such high quality as that made with the still purer fuel of rood charcoal.

It will thus be seen that at the rery threshold of the manufacture there are causes in operation that serionsly affect both the quality and the cost; and that, although in the manufacture of ordnance, a material of the very best description is the desideratum, still in the ride range of the arts there is, at the same time, a demand for erery quality. It thus happens, and that to a great extent, that price rather than excellence is the predominating influence that determines the manufacture.

Iron may be divided into three great classes; these are knorn as cast and wrought iron and steel; indeed, for all practical purposes, they may be looked upon as threo distinct metals.

Cast iron is the material as it runs from the first process of the smelting furnace, and is that from which both wrought iron and steel are made.

During the smelting process, the iron has absorbed a considerable quantity of carbon, as rell as still retaining sereral other ingredients and original impurities, the presence of which renders cast iron capable of being melted and remelted a number of times, and used for the various purposes of the iron-founder, and the metal is sufficiently liquid to admit of being poured into moulds of any form with the greatest facility; hence, if cast iron had the tonghness or strength, and the other good qualities of either of the other modifications of this metal, namely, wrought iron or stecl, it would necessarily have the preference, not only on account of its cheapness, but also from the great readiness with which it can be poured into almost any variety of intricate ontline, at a small expenditure of fuel, wages, or plant.

Cast iron, when considered as a material for the iron-founder of general articles, is mostly affected by the proportion of carbon which is present.

The carbon renders the iron more liquid when in the flud state, and softer when in the solid condition, at the same time it is not quite so strong in regard to its tenacity, although possessed of more toughness 
than iron containing a less quantity of carbon; hence the founder is to a great extent guided in the selection of pig-iron for particular articles by the quality of the compound.

For enstings where great strength is aimed at, considerable judgnent is necessary in the selection of a mixture that will secure all the conditions of softness or hardness, closeness of the grain, and that degree of toughness and strength, which may be necessary.

There are many instances on record of cast iron haring shown an amazing amount of strength, touglness, and general endurance, both as guns and in other constructions; still, at the best, it is uncertain, and, as will be seen hereafter, it is not strong, and is proverbially treacherous to depend upon, as it gires no warming before rupture; and hence the time has arrived when, for ordnnuce especially, it seems about to give place to a better material, either mronght iron or steel, or perhaps a combination of both.

The malleable, ductile, tongh, and fibrous material termed wrought iron, which is so extensirely used by the smith for every branch of art, is made directly from cast iron by an elinination from that compound of its carbon, sulphur, silicium, phosphorts, and other impurities, by a process of oxidation.

. This purification of cast iron produces a material with entirely different characteristics; it becomes much stronger, has greater toughness, is highly infusible; it loses the property of becoming liquid, and is therefore unfitted for the founder's purposes. It the same time, horrerer, it acquires another property, almost equally raluable, for, when brought to a high temperature, it acquires a riscous or sticky character, so that if different pieces in this condition are brought together, they adhere, and if a blow is given or pressure applied, the separate pieces are made to adhere permanently.

This remarkable property is termed welding, and is the basis of the art of forging, as practised by the smith.

The conversion of cast into vrought iron is effected in different ways, although the same principle is adopted in all, namely, to burn out the silicium and carbon.

One arrangement is, to drive oft these matters by fusing with charconl while a hot blast is playing on the liquid mass; but the more usual plan in this country is to subject the liquid to the rell-knomn process of puddling. The cast iron is melted in a furnace in which a hot oxidising flame is brouglit to bear upon the fluil ; by means of iron tools the mass is mored and stirred and turned orer in erery direction so as to expose crery portion of the iron, in turn, to the influence of the flame.

Under this influence it gradually loses its fluidity, and accuires the viscous or sticky property. It is then parted into lumps of a size suitable for manipulation; cach lump is afterrards suljected to a still further process of purification, and one which is dependent on another principle for its efficiency.

The lump of riscons iron may now be compared to a very dirty sponge that requires to be sereral times retted and wrung in order to make it pure and clean.

On its remoral from the puldling funace this lump of viscous iron matter, like a dirty sponge, is put under a heary hammer or other 
apparatns, the blows or equeezing of which drive of the impurities, and the mass is worked out still further by means of rolls into a long bar of coarse and dirty iron, unfit for the smith, and which is aftertrards cut into short pieces. Theso pieces are piled up into a bundle, and are again put into a furmace and subjected to another heating; the iron is again brought to the welding state for another washing, and is again subjected to another beating from the steam hammer, and a squeezing from the rolls, all which still further improre the purity and the quality of the iron bar.

For the production of the better descriptions of iron, this process of purification, of cutting up, re-relding, nnd hammering or rolling, is repented sereral times until the proper quality is attained. Of course such treatment, while it improres the material, also increases the cost in a still greater proportion.

Eren after the best treatment, the wrought iron of commerce is not chemically pure, although its combination with the grosser impurities does not seem to be of that intimate character that exists in cast iron. It still contains carbon, silicium, and other matters, which fill up the minute racant spaces between the fibres which compose the structure of the bar.

In consequence of the great aftinity which iron has for sulphur, phosphorus, and other impurities that affect its quality, the quality of wrought iron is much dependent on the character of the fuel employed in its manufacture; the purer the coal the better is the iron, and lence that which is made with wood-charconl is necessarily the purest and best, although, at the same time, it is most expensive.

The quality of wrought iron is also greatly dependent on the original selection of the mixtures of cast iron for puddling, and on the care, skill, and close attention which are brought to bear upon all its successire stages; hence iron comes to differ as much in its qualities and properties as any two materials of the same class could be expected to be capable of doing, and more so than that of any other similar substances with which I am acquainted.

IThis difference, howorer, is only detected when high conditions are aimed at, then close observation discloses inmumernble shades of quality, that escape the obserration of the majority of workers in iron, who use the material for purposes whero the object required is easily secured.

The conversion of cast into wrought iron by the remoral of carbon and silicium completely ehanges the characteristics of the material. It has lost the brittle property; it now yields and stretehes before it breaks; the permanent yielding point is now higher than the former breaking point, and the breaking point is double that of the yielding point.

These are all strong conditions in its farour, but at the same time it has many serions defects.

It is difficult to produce in large masses that are perfectly sound throughout; the smith or forgeman has little control or authority orer its behariour when in the welding furnace, and hence it is extremely difficult to produce large forgings perfectly soumd, even with the best treatment; there is, therefore, still great room for improvement, so as to ensure a perfectly homogeneous mass, possessing all the good properties of the malleable, welding, tough material, and which, at the same time, shall be fice from its numerous defects, reins, aud unsoundness; yet it is but just to 
add, that, with all its many defects, there is no material at the present time which can be so implicitly relied upon and trusted with so much security against fracture from sudden ribration, as a piece of good sound mrought iron.

The material called steel is an intermedinte compound betreen cast iron and the former material of monght iron.

Steel is comparatively a pure iron, containing a small per-centage of carbon with some other substance in combination, which is rather obscure, and regarding which there is considerable difference of opinion. This combination gires the material some rery peculiar characteristics of its own, and is entirely different in character from either of the metals out of which it is made.

Steel can either be made from wrought iron or from cast iron.

The latter arrangement is the cheapest process, but the former method affords the most certain results at the present time, and that is the system chiefly resorted to in making the finer qualities of steel.

To make good stecl of high quality, a bar of pure wrought iron is selected, mostly Sredish, which has been made with charcoal in all its previous stages. The iron bars are put into $n$ firc-brick chest, along with a quantity of charcoal porrder; crery part of the bar being surrounded with the carbon, the air being excluded, the whole is made white-hot, and kept in that condition for sereral days, generally about a meek, according to the amount of confersion that is required. During this period the pure white-hot iron imbibes a new property from the charcoal into its own nature.

A chemical action takes place, and the rrought iron has been thus gradually turned into steel. Such steel, howerer, is very imperfect. The defects are chicfly orring to its local irregularities of conversion, for although the cntire mass of the bar mas hare had the proper quantity of carbon put into it, yet it is found to be much improred through mixing the particles, either by relding several bars together into one bar, or even the mere rorking of a single bar under the lammer has the effect of cqualizing and greatly improving the quality.

The most effectunl waJ, horever, of obtaining a thorough mixture of the particles is to break the original steel bars into small pieces, then to melt them together in a crucible into liquid steel, and then to mix and pour this metal into an ingot, which, when solid, is then drawn into $\mathrm{a}$ bar of steel of the required dimensions.

By this means of putting carbon into pure iron, cast steel is produced, which is the finest in quality of any of the rarieties of this raluable metal. But good passable stecl can be made directly from cast iron, simply by not carrying the puddling process on to the full extent of wrought iron. Such matcrial is called puddled steel; and although at the present time it is not equal in quality to that which is macte in the other way, still it is rery much cheaper, and when more experience has been gained so as to determine the best descriptions of cast iron that are suitablo for this particular process, as also the precise period when to discontinue the puddling operation, so as to leare the proper quantity of carbon in the metal, there can be no donbt but that such cheap steel will be extremely valuable for many purposes, sceing that puddled steel is malleable, and has cren a higher tenacity than wrought iron.

A very fine material is now produced extensively by breaking up the 
rough bars of puddled steel and melting them into a cast steel, and which for many purposes is found equal to ordinary cast steel as made from Swedish iron; so far as I am arrare, homerer, it is not so good for edge tools.

Good steel can be made in a still more summary manner by means of the "Bessemer process." The crude cast iron, when in a melted state, is poured into a large refractory ressel previously heated, and a strong blast of air is forced through the fluid, producing a violent agitation.

The silicium and carbon in the iron unite with the oxygen in the air, and are driven off from the metal, until the remaining mass is almost pure wrought iron.

There is then added to the iron (in order to make it steel) a definite quantity of carbon; it is introduced in the condition of liquid cast-iron, of knorn mixture and quality; the whole is then thoroughly mixed, and the entire process is completed in about half an hour from the time of first pouring in the cast iron to the final running out of the stecl into moulds or ingots.

By the Bessemer process large masses of steel can be made more easily than by any other method yet introduced, and apparently at less cost, and there is no doubt that in time this process mill produce uniform quality.

Steel in all its combinations is a most valuable metal; in its ordinary state it is closer in structure, has greater power of resisting compression, and possesses a higher tenacity than wrought iron, eren of the best quality, and as such it commends itself to the engineer for the manufacture of the best class of articles, notwithstanding its greater cost, and the still greater cxpense which has to be incurred in its fabrication into the requisite forms. But it has another property, which causes it to transcend in Falue all otler metals, namely, the capability of being tempered to any degree of hardness or softness.

The discovery of the fact that a piece of soft steel, when lieated, and then suddenly cooled, no matter by what means, assumes a hardness approaching that of the diamond, is perhaps the most important of any in connexion with tho whole range of metals, and has been of the greatest service to mankind.

In addition to this property of hardening, when the said hard substance is exposed to a gentle heat, it gradnally begins to gire up a portion of its hardness, until at length it loses it altogether; and as it so happens that at the same time that the hardness is gradually departing, a definite change of colour of the surface of the steel accompanies the softening process, this change of hue becomes a correct measure of the change in hardness, and thus tho precise degree of hardness or temper that may be required for any purpose can be attained with great certainty and unifomity.

Steel, mrought iron, and cast iron can all be rendered softer and less brittle by means of the annealing process, which is simply causing the materials to be made red hot, then keeping them in that state for a short time, and afterwards allowing the whole to cool down very slowly, so that every part may cool at a uniform rate, and no part or particle be under any restraint from premature withdrawal of heat, thus cansing local contraction and hardness.

By prolonging the period of cooling, a mass of stecl comparatirely 
lrittle acquires the character of toughness in a remarkable degrec, and this process of annealing now plays an inportant part in all modem efforts to use steel either for guns or armour plates, or for anything exposed to jar or sudden ribration.

Such is a brief description of the metals-cast iron, wrought iron, and stecl-which are now attracting so much attention in the world, more especially in regard to their adaptation and application as materials for war purposes, and which are now to be shortly considered in regard to their sereral and relative fitness for the manufacture of rifled eannon of large calibre.

The numerous and repeated failures that hare occurred, and are still occurring, in the application of iron and steel for the abore purpose during the past few years, and eren at the present time, clearly show, that that which is wanted, necessarily implies some high conditions which are rery difficult to secure, and which appear all the more difficult to those who are the most concerned, and whose prorince it is to endearour to obtain them.

For small arms, and even for cannon of the smaller class, there is not much trouble experienced in applying almost any good material, whether bronze, iron, or steel; but in dealing with heavy breech-loading guns of large calibre, elements of weakness are brought into view which are exceedingly difficult to provide for and meet successfully.

The serere proof to which rifled guns are now subjected, consisting of seven romds, with two of the charges of gunpowder being equal to one quarter of the weight of the projectile, is found to thoroughly search and try their soundness, both in regard to the materials and the workmanship, and is sure to derclope any seriously defective part, if such exists; but the mere withstanding of the proof rounds is found not eren sufficient to thoroughly test the perfect soundness of a gun.

In wrought-iron guns, which have resisted proof successfully, minor defects will sometimes appear after a number of ordinary serrico rounds; such defects have required a repetition of charges to bring them out into riew for examination, each successive round acting like the blow of an enormous sledge-hammer, and gradually producing an alteration of form in the bore or in other parts of the structure.

Again, there are some of the stecl class of materials that hare been tried, apparently with great success, which have not only stood proof, but have been fired a great number of times, and yet prematurely have been ruptured; the effect of the firing secms to derange the crostallization, and to lave been like the repeated blows of the hammer driving home the wedge, until a separation of the particles is effected.

It is also found, however paradoxical it may appear, that the strongest material after a certain point, whetler of wrought iron or steel, makes the weakest gun; that wronght iron as it approaches the character of steel, while becoming better adapted in sereral respects, is getting all the worse in other respects still more important; and that when steel is annenled and otherwise treated, until it seems to be losing all the good qualities for which it is so celebrated, that then it is becoming all the better adapted for the sudden jar and vibration of a gun, but at the same time it is losing some of those good qualities which chiefly recommend it as a competitor with wrought iron for the construction of rifled cannon. 
So far as my present experience goes, we are still in want of the proper, the perfect material for the interior of the bores of large guns, a material that will afford bores inrariably sound and perfect, and which will remain so in the same manner as an ordinary musket barrel, and which at the same time shall be as safe against bursting, as guns built up of wrought iron on Sir William Armstrong's principle, which in that respect may be considered perfect, and as fulfilling all that is or can be desired or reasonably expected.

The extruordinary effect that is sometimes produced in the bores of rifled guns made of any description of metal which will not be in danger of bursting, from its hardness, is much greater than is generally supposed, and is only known to those who are more immediately concerned, ordinary bronze gum-metal being acted upon in the manner that lead wonld be, only in a less degree. The shot or shell in such rifled guns requiring considerably more power to set it in motion as compared with the round ball from a smooth bore-the abrupt check of the warc of gas suddenly arrested in its progress-the amount of work to be done in whirling the projectile up to such a velocity in so short a space of time-the lengthened period during which the pressurc exists in the rifled gum-as also the extremely violent action of the highly worked gunpowder which is used in England,-all these causes combine to render the effect of the powder upon the interior of large rifled guns rery considerable, and involve a high standard of quality in the materials employed.

Before considering the fitness of any particular metal for the manufacture of rifled guns, let us enumerate some of the propertics mhich are absolutely requisite to insure perfection.

The desideratum, then, for the interior and general structure of rifled guns is a material which should possess all the following characteristics :-

1st. That it shall be capable of withstanding the riolent action of the most active gunpowder against rifled projectiles without producing the risk of fracture or even inordinate deterioration in the bore, and that it shall not be in danger of bursting at any future time by the cffect of contimual firing causing deterioration of the quality of the metal.

2nd. That the material to be employed shall have sufficiently high tenacity and general strength as will not render necessary the emplojment of a greater weight of gum than what is considered requisite by the artillerist to absorb the recoil.

Brd. That the material shall be sufficiently hard, so that the surface of the interior of the bore shall not in any way be indented or bruised, or otherwise acted upon, by the powder or projectile, or even by the premature fracture or explosion of a cast-iron shell within the bore.

4th. That the material shall be such, as that guns can bo easily manufactured without much risk of radical defects, and that the guns, when properly made and proved, may with confidence be considered right in all respects, and witlout any doubt or uncertainty as to their positive soundness or future stability when in actual service.

5th. That the guns when made shall not be too costly.

Haring already hinted that none of the existing metals, whether cast iron, wrought iron, steel, or cren bronze, so far as I am arare, fulfil their function in all these conditions, still, haring no other available souree but 
these, especially iron or steel, to fall back upon, let us consider some of their respective properties, and appreciate their fitness in proportion to their sereral merits; that being the best which promises these sereral conditions in the highest degree, and in the order of their greatest importance to the soldier in the hour of battle.

In arder to be able to arrive at a correct comparison of the sereral metals, it is not only necessary to know definitely their respective resistance to compression and extension, but we also want to know with equal certainty their relative toughness, elasticity, and general behariour, when exposed to strain combined with extreme vibration.

In regard to these tro Iatter properties, little has yet been done to reduce them to the actual test of definite experiment, hence we can only infer from the general facts shown by the behaviour of the guns constructed of the several materials, and, as a rule, this is a very safe guide, providing there is sufficient experience on which to guide the judgment.

Witl regard to the strength of the sereral materials, especially their resistance to compression and extension, therc are abundant data and full opportunity of obtaining positire knowledge so far; from which, howerer, if the other properties of toughness and elasticity are not considered, we are apt to draw a rery unsafe conclusion.

With reference to the first of these properties, namely, compressibility, it is remarkable that the resistance to compression in cach of the three materials referred to is more nearly equal than any of their other properties.

The pressure per square inch which is required in either metal to produce a permanent sensible indentation or shortening, about equal to three thousandths of an inch in measurement, ranges from $30,500 \mathrm{lbs}$. to 10,700lbs.

This does not refer to the ultimato force which is required to crush the specimens into fragments, because for a gun that is of no consequence, as such an extreme test is not called into requisition. The proper material must be such that there is no sensible compression produced in the ricinity of the bullet-chamber by the force of the explosion or projectile. Hence the measure of strength or fitness is the point where the material begins to set permanently, and, so far, that is the best material which requires the greatest pressure.

Ten specimens of cast iron, parts of guns of the highest quality, but which have been sererally burst, gave $35,000 \mathrm{lbs}$. per square inch; producing an averago compression of three thousandths of an inch. The softest being $30,000 \mathrm{lbs}$, the hardest $40,300 \mathrm{lbs}$.

Ten specimens of rolled mrought-iron bar, made specially for guns, the specimens being eclected at random and reduced from bars three inches square, all of the highest quality and suitable for guns, garc an arerage of 33,000lbs. per square inch, with an arerage compression of three thousandths of an inch. The softest requiring $31,000 \mathrm{lbs}$., the hardest 35,000lbs.

Ten specimens of wrought iron, cut from large gun-forgings of superior quality, gare an arerage of $26,900 \mathrm{lbs}$; producing an arerage compression of three thousandths of an inch. The softest being $22,800 \mathrm{lbs}$., the hardest 31,000 lbs. 
Ten specimens of coft cast steel of tho finest quality, and that either withstood the proof-rounds, or which failed before the seren proof-rounds were completed, gave an average of $35,500 \mathrm{lbs}$. per square inch, with an arerage compression of three thousandths of an inch. The softest being $25,000 \mathrm{lbs}$., the hardest $46,000 \mathrm{lbs}$.

Ten specimens of cast steel, more highly conrerted than tho former, and in quality almost fit for cutting instruments, but which broke first round at proof, gare an average of 76,000 lbs. per equare inch, with an arerage compression of three thousandths of an inch. This kind of steel therefore need not be considered as of any raluc, howerer good in other respects, it being totally unfit for guns or armour-plates from its brittleness or want of the necessary toughness to withstand the ribration.

A specimen of cast steel, cut from a gun made by Mrr. Krupp, of Essen, but from a gun which failed at proof, gare 25,300 lbs. per square inch, with a compression of three thousandths of an inch.

Four specimens of steel and iron, welded together like lajers of sandwiches, gare in the direction of the fibre, that is, pressing the steel and iron upon the edge of the sandrich, an arerage of $26,000 \mathrm{lbs}$ per square inch, with an arerage compression of three thousandths of an inch.

Four specimens upon the flat of the sandwich, thus pressing the two metals closer together, gave an average of $25,400 \mathrm{lbs}$. per square inch, with an arerage compression of three thoueandths of an inch.

It will thus be seen, according to these experiments, which were all made on carefully prepared specimens, exactly one iuch in Iength and half an inch in diameter, that the arerage resistance to threo thousandths of an inch compression, or shortening, was as follows :-

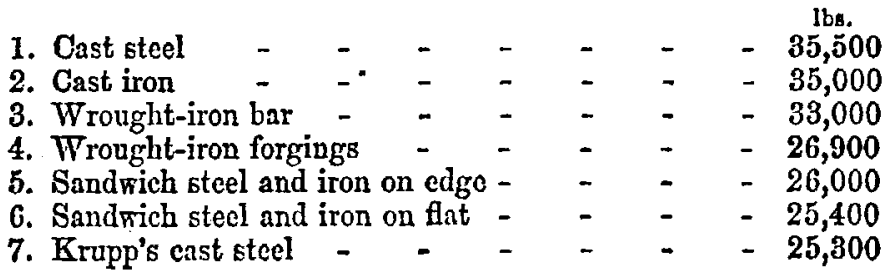

The chief point to be obserred in regard to the compression of cast steel, which is the highest on the list, namely, $35,500 \mathrm{lbs}$., is the wide range from the softest to the hardest, from $25,000 \mathrm{lbs}$. to $46,000 \mathrm{lbs}$; this characteristic of want of uniformity is found to be its prerailing feature and failing, and is the case with all the stecls, eren from the best houses which hare come under my examination; and from the nature of its manufacture it is perhaps impossible to make steel positirely uniform.

But if it could be made uniform, and if to the harder steels could be superadded the property of toughness so as to kecp together, and if at the same timo the brittleness could be withdrawn so as to gire it the opportunity of recorering from vibration, it would then be inraluable both for guns and armour-plates; but so long as the cast-steel manufacture is uncertain in its produce, no matter how good it may be occasionally, the gunmaker will look upon it with suspicion, as a single failure produces so much mistrust. 
The sccond on the list is cast iron, which is also rery high, 35,000 lbs., and so far is good, but, like stecl, it has also a wide range, from $30,000 \mathrm{lbs}$. to 40,300 lbs. If this metal had tenacity and toughness in proportion to its incompressibility it would, from its cheapness, hare the decided preference; but so long as England is aiming at high results in her gunnery, the want of those properties will prore a strong objection to its adoption for rifled guns, unless cast iron can be much improved in tenacity and made more certain in its general character.

The third on the list is wrought-iron bar at $33,000 \mathrm{lbs}$., with the small range of from $31,000 \mathrm{lbs}$. to $35,000 \mathrm{lbs}$; and this is the peculiar feature of wrought iron, it is nerer high nor nerer low; on the contrars, wrought iron from any particular maker, who is careful in the manufacture, is found to be nearly uniform, and, being possessed of great toughness and being without brittleness, it is exceedingly reliable so far as its strength will permit.

The fourth is that of wrought-iron forgings, which is considerably under bar iron, $26,900 \mathrm{lbs}$, also with a mider range than bar, and hence the less raluable so far-from $22,800 \mathrm{lbs}$. to $31,000 \mathrm{lbs}$.; the hardness and softness of large forgings being so much aftected by the locality of the bloms upon the mass.

The fifth and sixth upon the list are the Sandwich specimens, which are not of so much importance, except that as combinations they hare been found to stand in some applications where steel failed from brittleness, and where soft iron was found to yield from lateral bulging; and no doubt the low position is partly clue to the condition of the iron, and also to the soft quality of the steel which was necessarily used in order to get a good sound relding betrreen the trro classes of material, the iron and steel.

The softest material on the list is the famous cast steel made by Mrr. Trupp of Essen. Only two specimens rtere operated upon, and gare 25,300 lbs. As will be seen, the hardness of this material is considerably under wrought iron, and, so far, is that much inferior in this respect. This material is so soft as to admit of being flattened down to any extent; indeed, the same remark applies to most of the good qualities of steel which are under $40,000 \mathrm{lbs}$; t they continually yield more and more by the increase of pressure, and the structure of the steel shows a wonderful adaptation for keeping together without cracking at the edges, unlike almost any of the other descriptions of material. This property is greatly in its farour, both for guns and armour-plates; and if it could be made to resist a sudden shock as well as it does the effect of mere pressure, it would be cxceedingly raluable.

It will thus be seen that the sereral classes of material here referred to do not differ so much in the foregoing respect as might be expected, unless we are to include the extremely hard qualities of steel, which are from their liardness and brittleness obviously unfitted for guns; such qualities of steel rise up to $80,000 \mathrm{lbs}$., and can only be made available for the purposes in question by a long course of annealing, which is a process that may be continued until the netal is as soft as the lowest specimens which hare been referred to; such softness, howerer, diminishes their value in proportion to its amount.

In regard to thic other property, namely, that of tenacity, there is a 
much greater difference existing between the cast iron, wrought iron, and steel, and it has also to be obserred that they differ still more in their amount of elasticity and capability of stretcling before fracture.

Cast iron and hard steel invariably. break at the moment of perceptible elongation when the specimens operated upon are in short pieces, while wrought iron and soft sted have a considerable' nmount of elasticits, and only begin to permanently elongate after a certain load per square inch has been suspended, and they gradually continue to stretch with erery increase of load until final rupture takes place.

As the mensure of strength of any material wherewith to construct a gun, is the point at which permanent elongation commences, that point should have the chief attention; still it is requisite for comparison to specify the ultimate strength as well, in order to show the margin of strength which lies beyond this point; thus the several metals can be compared in regard to their relative fitness so far as the property of tenacity is concerned.

From sereral hundred experiments made with the higher qualities of cast iron which were collected with a view to obtain the strongest iron for cast-iron guns, the ultimate tenacity was fonnd to range from $10,886 \mathrm{lbs}$. up to 31,480 lbs., or an average of 21,173 llss. per square inch.

This is considerably above the strength of the greater proportion of the cast iron of commerce. The arerage of the Nova Scotia iron, specimens of which have recently been tested, gave only $15,821 \mathrm{lbs}$, and some of the Scotch pig-iron selected at random only gave 12,912 lbs.

It will be observed that the foregoing are the ultimato breaking points of cast iron, and gare no stretching or appreciable warning before fracture.

Of late years, and up to the present time, cast iron has generally been used for heary guns, but its low tenacity and brittle, uncertain character reuders it peculiarly unfitted for this purpose, and more especially is it unfit for rifled guns, as in them not only is the strain considerably incrensed, but the duration of the strain is prolonged in addition, thus producing a rupture before the particles have recovered from the vibration.

It is therefore inferred that, until an element of tonghness can be given with certaints to that weak material; it can nerer be thoroughly depended upon in the construction of the armament of the future, notwithstanding its cheapness and facility of construction.

Although a small piece of cast iron mder the testing process gires no warning, yet cast-iron guns which hare stood the proof rounds, if closely watched, begin to show the lines of future failure long before the period of ultimate fracture, and the practised observer can generally indicate the probable number of rounds that will elapse before the gun gires way altogether.

At the same time there are several instances on record of cast-iron guns haring exhibited an extraordinary amount of endurance, but the touglmess is variable and uncertain, and nothing uncertain is to be commended.

From sereral hundred experiments that hare been made with wronght iron cut from bars intended for the manufacture of Arnstrong guns, the folloming result has been obtained.

The point of yielding permanently gives an arerage resistance of $28,000 \mathrm{lbs}$. per square incli, while the point of ultimate rupture gires an arerage of 57,120 lbs., or rather more than double that of the point where 
permanent elongation commences; the margin that lies between these two amounts is of great importance as a condition of safety, but the chief point is that where the stretching begins.

After the first yielding by the addition of extra peight, tho wrought iron specimen gradually stretches until it has been considerably reduced in diameter; and such parts as have been so reduced hare a greater tenacity per square inch than when in the prerious normal condition. The iron has to a small extent assumed tho character of mire, which from the draring process is always stronger than the iron out of which the wire is made.

This increase, however, if given to wire, is lost afterwards when the iron or rire is brought to a relding heat, and hence for gun purposes this property cannot readily be taken adrantage of.

From ten specimens of wrought iron cut out of heary forgings, a lorrer result has been obtained than from bar iron, such forgings being inferior in all respects.

In such masses, from their not having an equal amount of working in proportion to the extent of heating to which they are cxposed, the tenacity is not so high as that of the more highly worked rolled iron when it comes direct from the rolls. In forgings, the arerage point of yielding permanently was $23,760 \mathrm{lbs}$. - average noint of ultimate fracture being $48,160 \mathrm{lbs}$. The forgings from which the specimens were cut were all of high quality.

When rolled bars of the best quality are wound into coils, and then welded into cylinders for gun manufacture, the iron as a general rule is found to suffer to about $3,481 \mathrm{lbs}$. per equare inch on the arerage.

The following shows the arerage results both in regard to yielding and breaking :-

$$
\begin{aligned}
& \text { Yielding }\{\text { Irou in bar - }-\quad-31,100 \\
& \text { point. \{ " cylinder - } \quad \mathbf{2 7 , 8 5 2} \\
& \text { Rupture }\{\text { Iron in bar - }-\quad \text { - 58,986 } \\
& \text { point. }\{\text { " cylinder - } \quad 55,500
\end{aligned}
$$

The loss is due to the necessary leating being greater in proportion than the working.

From experiments that have been made to ascertain the tenacity of welds of iron of different qualities, and under different circumstances, it has been found that with iron of the finest quality, when brought to the proper heat in a firo free from impurities in the fucl, and with the joint scarfed so as to increase the area, the strength is equal to that of the solid iron, which is of course all that could be desired, and is in round numbers about 25 tons, or $56,000 \mathrm{lbs}$. per square inch.

With all other descriptions of roldings which I hare yet tested, the result is lower than the abore, down even to $12,000 \mathrm{lbs}$. per square inch, the same care having been obserred in erery instance.

Tro pieces of the best quality of iron butted together, under the best conditions which I hare been able to effect up to the present time, hare only giren an average ultimate tenacity of $32,140 \mathrm{lbs}$. per square inch, which is only a little over the half of the iron bar.

Iron butt welded to steel under the best conditions invariably breaks at the weld, and showa only an nrerage tenacity of $26,800 \mathrm{lbs}$. 
But even this depends entirely on the nature of the iron and the steel; any increase of hardness or of the steely property, either in the iron or in the steel, affects the strength of the meld in many cases'down to 10,000 lbs. and eren still lower.

In the construction of the Armstrong guns the bar iron is first round into a spiral coil, and then a welding heat is taken through the entirc mass, and by means of a steam hammer it is welded into a homogeneous cylinder.

With iron of the rery best quality which we hare as yet been able to obtain, the highest arerage tenacity of the relding of the coil has been 32,140 lbs. per square inch, the iron being $55,500 \mathrm{lbs}$.

With other iron also of high quality and of still greater tenacity, the welds have been lower down, eren to 10,000 lbs. per inch; hence such iron, however strong, is, from the steely property, unsuitable for being made into coils; the defect being due to the reluctance shown by harder and stronger iron to unite when raised to a temperature that will not otherrise injure the quality of the material, and cause it to blister.

It will thus be seen that the ultimate strength of a coil in the circumferential direction is about $55,500 \mathrm{lbs}$. per inch, while in that of its length it is only $32,140 \mathrm{lbs}$. per inch, and when strouger and harder iron is emplojed it is even much less in the latter direction and the difference is proportionately greater; lience such steely iron must be aroided for purposes where much dependence has to be put on the relding.

In builiting up guns of cylinders, this high tenacity afforded by the coil system circumferentially, and the opportunity which it gires of knowing the soundness of the gum structure in crery part, and from the fact that every part of the gun is put under the full exercise of its duty from the commencement,-this arrangement of building up guns will always have an immense advantage over guns made of a single solid forging in point of strength and security against bursting of the whole structure; and cren when the coiled cylinder is considered as a means of obtaining the inmer lining or bore of a rilled guu, a purpose for which it is by no means so perfect, jet cren in that respect it is superior to the bore which is formed within the heart of an immense forging, of dimensions suitable for a large grun, such a mass of forging being always more or less defectire eren under the best and most careful worknanship.

This remark does not apply with the same foree to the bores of guns when formed from a smaller forging in which the exterior only has been left as a shell or tube; the outside of such a forging, when properiy treated, has a tenacity in all directions equal to that of the solid forging, consequently it is not co strong as the coil in the circumferential, at the same time it is considerably stronger in the longitudinal, direction, and is much more free from defects than the heart of a greater mass in larger forgings.

Turning to cast steel, $\pi c$ find that the range of tenacity is extremely wide-from 114,000 lbs. domn to $67,000 \mathrm{lbs}$. per square inch - but it so happeus that the higher qualities, judging from Woolwich experience, are altogether unsuited from their brittleness and great tendency to fracture, and, considering that no metal should be taken into account but that which can be depended upon, I shall only refer to qualities that hare been successful in resisting the proof ronnds. This quality arerages about 
$80,000 \mathrm{lbs}$., and it is generally found that the weakest are really the strongest, and if the supply of snitable steel conld be obtained with unvarging precision in regard to that degree of hardness, tenacity, and toughness, which is sometimes produced, it would be all that could be desired; but, unfortunately, it is fickle, treacherous, and uncertain, and hence for certain parts of the Amstrong gun that were formerly of steel, and for which some of the properties of steel are desirable, wrought iron of fine quality is now substituted, which, so far as not brealing is concerned, answers the purpose most satisfactorily, although not so good as steel in other respects.

The gun supplied by Mr. Krupp, which was formerly referred to, lut which failed nt proof, gave a tenacity of $72,000 \mathrm{lbs}$.; judging from the appearance of this metal beforehand, its softness and perfect soundness, I had great expectation of its being all that could be desired, but was disappointed.

Such a mass of homogencous steel, after haring been cast into an ingot, all its impurities floated to the surface, then well worked under the hammer, and aftertrards properly annealed, has a degree of perfection in the bore in regard to entire freedom from specks, seams, or flaws, superior to any wrought-iron structure, coiled or forged, and some remarkably fine guns hare been constructed with such steel linings, haring the main structure of the gun built up with wrought-iron hoops to give the requisite strength to the steel lining. Such a combination gives the perfect bore and the strong gun, hut there is not yet sufficient experience to enable me to assert positirely, that the steel will not give way under long-continued firing; but the great difficulty lies in the inability of the steel-maler to insure uniformity, for an occasional gun bursting destroys all confidence.

Such are the sereral metals now used as materials for gums. Cast iron is the cheapest but the least trustworthy. Wrought iron, built of coiled cylinders, will afford the greatest strength, and is the least likely of all to burst by continued firing; and although in the first instance it will cost three times as much as a cast-iron gun, yet, as its endurance is more than ten times greater, judging from recent results, and as it is nerer likely to burst with any reasonable amount of firing, $I$ consider it the safest inrestment, eren in a money point of view.

The wrought-iron solid-forged gun, when moderately sound, is much superior to the cast-iron gun, but is inferior to the built-np mrought-iron gun; and, considering the chances of defective bores in the large masses of solid forgings, it will be found as expensive as the latter, and not nearly so reliable.

Cast steel is the most expensire of all, yet, from its somdness in the bore, if it could be made as trustrorthy as wrought iron, and if at the same time it could be depended upon for the certain possession of toughness, it would be perfection, notwithstanding the cost; but the uncertainty of manufacture which now exists must first be completely remored before it can be compared with wrought iron as an instrument for men to fire and stand alongside with perfect assurance of safety; and, as rrought iron is so reliable and the cost moderate, there is no particular want felt for steel to constitute the entire body of the gun.

What the rorld requires is a quality of steel that will be perfectly reliable as an interior lining to $n$ mrought-iron built gun; such a com- 
bination will secure all the conditions that are wanted to mect the requireinents of the artillerist at the present time.

Such steel should be consitierably harder than wronght iron, at the least equal to $50,000 \mathrm{lbs}$. required to produce sensible shortening on a square inch, but at the same time it must be without brittleness and possessed of toughness at least equal to soft wrought iron, entirely free from honeycomb defects throughout, and which can be produced in a manner and by a process so definite, that there will be no change in the supply and no risk run of uncertainty in the quality of a crystalline structure that shall not bo rendered brittle ly continued firing, but which shall be as pernanently safe and hold on, like good sound wrought iron.

These are high conditions not yet reached, so far as I am aware-not that it is not oceasionally attained by some of the best steel makers, and hence there is hope to encourage persererance; but at the present tine, cren with the greatest care, the precise quality is uncertain ; still, by inferring from the progress recently made in the manufacture of iron and steel, and the great adrantage which will accrue to those who are successful, we may reasonably expect that, by aiming high and with a welldirected effort, those conditions will ultimately be realized, and the gummaker, by a judicious combination of a steel bore within a built-up wronghtiron structure, will be enabled to give the soldier a perfect instrument on which he can implicitly rely, and which will last for ages; meanmhile, considering the materials of iron and steel, as we now find them, and after balancing all the sereral adrantages and disedvantages, mrought iron is the most reliable, even if not so perfect in other respects. 